OPEN ACCESS

Approved by:

Frontiers Editorial Office,

Frontiers Media SA, Switzerland

*Correspondence:

Evangelia Tzika

evangelia.tzika@4sc.com

Axel Imhof

imhof@lmu.de

Specialty section:

This article was submitted to Epigenomics and Epigenetics,

a section of the journal

Frontiers in Genetics

Received: 04 April 2020

Accepted: 06 April 2020

Published: 23 April 2020

Citation:

Tzika E, Dreker T and Imhof A (2020)

Corrigendum: Epigenetics and Metabolism in Health and Disease.

Front. Genet. 11:428,

doi: 10.3389/fgene.2020.00428

\section{Corrigendum: Epigenetics and Metabolism in Health and Disease}

\author{
Evangelia Tzika ${ }^{1,2 *}$, Tobias Dreker ${ }^{1}$ and Axel Imhof ${ }^{2,3 *}$ \\ ${ }^{1}$ 4SC AG, Translational Pharmacology, Munich, Germany, ${ }^{2}$ Faculty of Medicine, Ludwig Maximilians University of Munich, \\ Munich, Germany, ${ }^{3}$ Protein Analysis Unit (ZfP), Biomedical Center, Ludwig Maximilians University of Munich, Munich, \\ Germany
}

Keywords: epigenetics, metabolism, cancer, diabetes, HDACs, HATs, methyltransferases, demethylases

\section{A Corrigendum on}

Epigenetics and Metabolism in Health and Disease

by Tzika, E., Dreker, T., and Imhof, A. (2018). Front. Genet. 9:361. doi: 10.3389/fgene.2018.00361

In the original article, there was an error in the Acknowledgments section. The selected icons used for Figure 1 with permission under the free license were sourced from two icon supply websites which have transferred ownership. As the current content on the websites have no relevance to our research, we have removed the respective links and the Acknowledgments section.

The authors state that this does not change the scientific conclusions of the article in any way. The original article has been updated.

Copyright () 2020 Tzika, Dreker and Imhof. This is an open-access article distributed under the terms of the Creative Commons Attribution License (CC BY). The use, distribution or reproduction in other forums is permitted, provided the original author(s) and the copyright owner(s) are credited and that the original publication in this journal is cited, in accordance with accepted academic practice. No use, distribution or reproduction is permitted which does not comply with these terms. 